\title{
Serological Specificity of Yeast Mannan
}

\author{
By I. CAMPBELL AND R. H. GILMOUR \\ Heriot-Watt University, Edinburgh, EHI I HX
}

(Accepted for publication 22 August 1969)

\begin{abstract}
SUMMARY
Soluble serologically active preparations extracted by various methods from Saccharomyces spp. showed the group specificity previously detected by agglutination tests with whole cells. The antigenic properties of the four serological groups of the genus Saccharomyces are probably determined by the cell wall mannan.
\end{abstract}

\section{INTRODUCTION}

Antigenic analyses of yeast species have depended mainly on agglutination tests with whole cells (Tsuchiya, Fukazawa \& Kawakita, I96I; Campbell, I968) but watersoluble polysaccharide material, presumably from the cell wall, has also shown antigenic differences between species of the genera Saccharomyces and Candida (Summers, Grollman \& Hasenclever, I964; Suzuki, Suzuki, Yokota, Sunayama \& Sakaguchi, 1967). Gel-diffusion methods have been used successfully with saline extracts (Sandula, Kockova-Kratochvilova \& Zamecnikova, 1964), phenol extracts (Campbell, Robson \& Hough, 1968) and mannan preparations (Summers et al. 1964) against Saccharomyces or Candida sera prepared by immunisation of rabbits with whole cells.

Campbell (1968), by means of four suitably absorbed antisera, classified 19 species of the genus Saccharomyces into four antigenic groups A, B, C and D. These results obtained by agglutination tests were consistent with the observations of Sandula $e t$ al. (I964) in gel-diffusion experiments with various Saccharomyces species. Yeast mannan oligosaccharides were characteristic of species (Stewart \& Ballou, 1968) and reacted with yeast antisera, blocking the immune reaction against whole yeasts (Suzuki \& Sunayama, I968; Suzuki, Sunayama \& Saito, I968). With the exception of Snider \& Miller's (1966) report suggesting protein as the major cell wall antigen of yeasts, all previous work has indicated that the polysaccharide fraction, and probably the mannan, is the determinant of antigenic activity of Saccharomyces species.

Cell-wall material was isolated from typical strains of the four groups of our antigenic analysis scheme and the antigenic properties of these fractions are described below.

\section{METHODS}

Strains. Strains and routine methods of culture were as described by Campbell (1968); cultures were identified and classified according to the system of Lodder \& Kreger-van Rij (1952). Two strains were chosen of each of the antigenic groups A, B, $\mathrm{C}$ and D (Campbell, I968) for serological tests. Saccharomyces microellipsodes 698, of group D (unpublished results), was chosen as the second strain of that group. Large quantities of yeasts were grown in 15 litres of Sabouraud glucose broth in 20-litre bottles for 3 days at $25^{\circ}$. Aeration at $0.8 \mathrm{litres} / \mathrm{min}$. through a sintered-glass diffuser at 
the base of the bottle also served to agitate the culture. Yeasts were washed thrice with water, and the final centrifuged deposit was stored at $-15^{\circ}$.

Extracts. Isolated cell walls were prepared by the method of Trevelyan (1966). Phenol extracts were prepared by the method of Westphal, Lüderitz \& Bister (I952); only the water phase was retained as antigen (Campbell et al. 1968). Hot water extracts were prepared by shaking approx. $10^{9}$ yeasts $/ \mathrm{ml}$. at $68-70^{\circ}$ for I hr. Mannans were prepared by the method of Peat, Whelan \& Edwards (1961). Also, antigenic material was recovered from the cell-free supernatant fluid of a 3-day culture at $25^{\circ}$ in Difco yeast carbon medium plus glucose. All preparations were dialysed overnight against running tap water and freeze-dried.

Serological methods. Antisera were prepared and agglutination and gel-diffusion tests performed as described previously (Campbell, 1968; Campbell et al. 1968). Absorbed antisera used for gel-diffusion tests were freeze-dried and reconstituted, with distilled water, to the volume required to give homologous agglutination titres equal to those of the unabsorbed sera used in gel-diffusion tests with similar extracts.

Chromatography. Approximately $500 \mu \mathrm{g}$. of each extract were hydrolysed with $3 \mathrm{ml}$. of $2 \mathrm{~N}-\mathrm{H}_{2} \mathrm{SO}_{4}$ for $2 \mathrm{hr}$ at $100^{\circ}$. The hydrolysates were neutralised with $\mathrm{BaCO}_{3}$, deionised with mixed resin (Amberlite IR I 20 and Amberlite IR 45, B.D.H. Ltd.), reduced in volume and chromatographed on Whatman no. I paper. Descending chromatography was used with ethyl acetate + pyridine + water $(10+4+3 \mathrm{v} / \mathrm{v})$ as the solvent. Reducing sugars were detected with alkaline $\mathrm{AgNO}_{3}$ (Trevelyan, Procter \& Harrison, 1950) or aniline oxalate (Partridge, 1949). Glucose, mannose and ribose were used as standards.

\section{RESULTS}

Reducing sugars. The cell-wall preparations on hydrolysis contained glucose, mannose and traces of ribose. Similar chromatograms were obtained from hydrolysed phenol extracts and hot water extracts of whole yeasts, but the minimal medium preparations showed only glucose and mannose. Mannan preparations yielded mannose with only traces of glucose.

Protein content of extracts. All freeze-dried mannan preparations and phenol extracts contained less than $0.1 \%$ protein, measured by the method of Opienska-Blauth, Charezinski \& Berbec (1963) against a standard of bovine serum albumin (B.D.H. Ltd.). Hot water extracts contained 1-2\% protein, depending on the yeast species, and minimal medium extracts, up to $\mathrm{I} \%$.

Comparison of gel-diffusion and slide agglutination tests with unabsorbed antisera. Since previous reports from various authors have dealt with soluble antigens prepared in different ways, gel-diffusion tests with mannan, hot water and phenol extracts and antigenic material recovered from minimal medium were compared with our previous results by agglutination tests. The two strains of each antigenic group were tested with unabsorbed antisera to the following strains: group A-Saccharomyces carlsbergensis III6; group B-S. fragilis I00 and $S$. marxianus II I; group $\mathrm{C}-S$. willianus I06; group D-S. fermentati I6I. Saccharomyces marxianus antiserum was added to the series as a result of preliminary experiments in which certain discrepancies were noted between the standard group B $S$. fragilis antiserum and the serum against $S$. marxianus, apparently group $B$ but which on occasions reacted weakly in addition as a group $C$ serum. 
Gel-diffusion tests of the various extracts against unabsorbed antisera showed general agreement with the agglutination tests as shown in Tables I-5. However, unabsorbed antiserum to Saccharomyces carlsbergensis strain III6 agglutinated $S$ ellipsoideus Y 4 and $S$. willianus I06 (Table I) but produced no precipitin reaction with any of the extracts of these two strains (Tables 2-5). The same serum agglutinated $S$. fragilis I00 and $S$. marxianus II (Table I), reacted with the mannans (Table 2), minimal medium extracts (Table 4) and hot water extracts (Table 5) of these strains but showed no precipitin lines with their phenol extracts (Table 3). Antiserum to

Table I. Agglutination of Saccharomyces suspensions by unabsorbed anti-Saccharomyces sera

Agglutination by antiserum to:

\section{Agglutinable suspensions}

Group A:

$S$. rouxii

Group B:

S. fragilis

S. marxianus

Group C:

$S$. cerevisiae var. ellipsoideus

S. willianus

Group D:

$\begin{array}{ll}S . \text { fermentati } & 16 \mathrm{I} \\ S . \text { microellipsodes } & 698\end{array}$

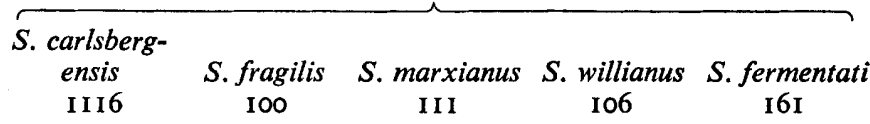

$$
+=\text { agglutination; }-=\text { no reaction; } \pm=\text { variable. }
$$

Table 2. Precipitin tests of Saccharomyces mannans by unabsorbed anti-Saccharomyces sera

Precipitin bands formed by antiserum to:

\section{Mannan \\ solutions}

Group A:

S. carlsbergensis 396

$S$. rouxii

170

Group B:

S. fragilis

$S$. marxianus

100

III

Group C:

$S$. cerevisiae var. ellipsoideus

S. willianus

$\mathbf{Y} 4$
$\mathbf{I} 06$

Group D:

S. fermentati $\quad \mathrm{I} 6 \mathrm{I}$

S. microellipsodes 698

\section{S. fragilis} 100
S. carlsberg.

II 16

$+$

$+$
S. marxian

I I I $\overline{-}$

$\pm$
$+$ 
S. fragilis 100 agglutinated S. carlsbergensis 396 and S. rouxii 170 (Table I) and produced precipitin bands with all except phenol extracts (Table 3 ). This antiserum failed to agglutinate $S$. ellipsoideus Y 4 or S. willianus IO6 (Table I) but gave precipitin lines with all extracts of these strains (Tables 2-5). Antiserum to the other group B yeast, $S$. marxianus strain III, differed from that against $S$. fragilis 100 in agglutinating S. willianus 106 and S. ellipsoideus Y 4 (Table I). Antiserum to S. willianus I06 did not react with the minimal medium extract of $S$. fragilis Ioo (Table 4) or with hot water extracts of Ioo or S. marxianus I I (Table 5), but agglutinated these yeasts (Table I)

Table 3. Precipitin tests of Saccharomyces phenol extracts by unabsorbed anti-Saccharomyces sera

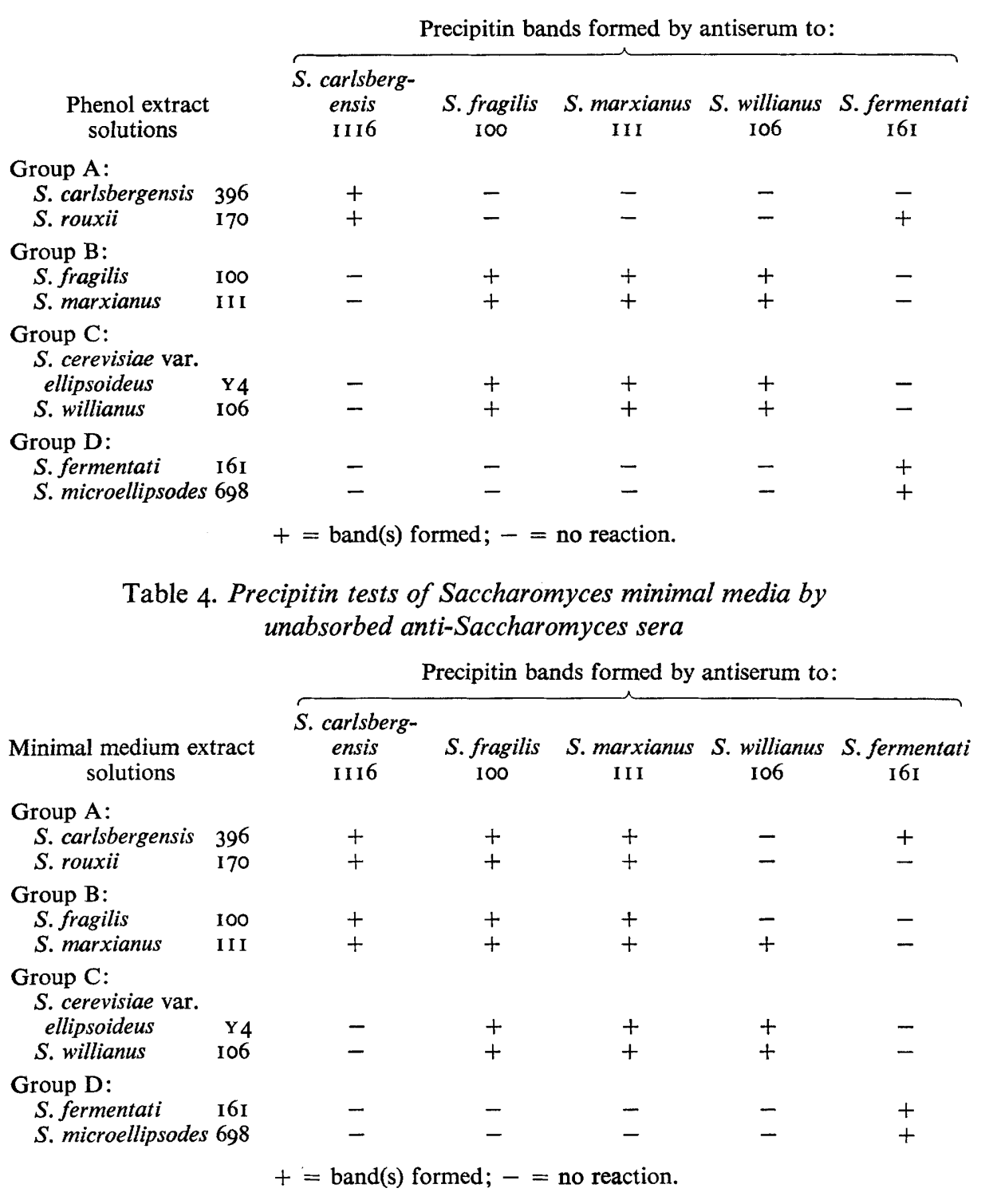


and gave precipitin bands with mannan and phenol extracts (Tables 2 and 3). Unabsorbed antiserum to $S$. fermentati I6I agglutinated $S$. carlsbergensis $396, S$. rouxii 170 and $S$. marxianus I I I (Table I), but gave consistent precipitin bands with only the mannan and phenol extracts of $S$. rouxii 170 (Tables 2,3 ) and the minimal medium preparation of $S$. carlsbergensis 396 (Table 4).

Since the mannan-containing enzyme invertase occurs in the yeast cell wall (Neumann \& Lampen, 1967), it was possibly implicated in these reactions. A sample of yeast invertase (B.D.H. Ltd.) was dialysed against distilled water at $2^{\circ}$ to remove glycerol, and lyophilised. The invertase was reconstituted at various concentrations for gel-diffusion tests against antisera to Saccharomyces willianus 106 and S. fragilis 100, but no reaction was observed.

Table 5. Precipitin tests of Saccharomyces hot water extracts by unabsorbed anti-Saccharomyces sera

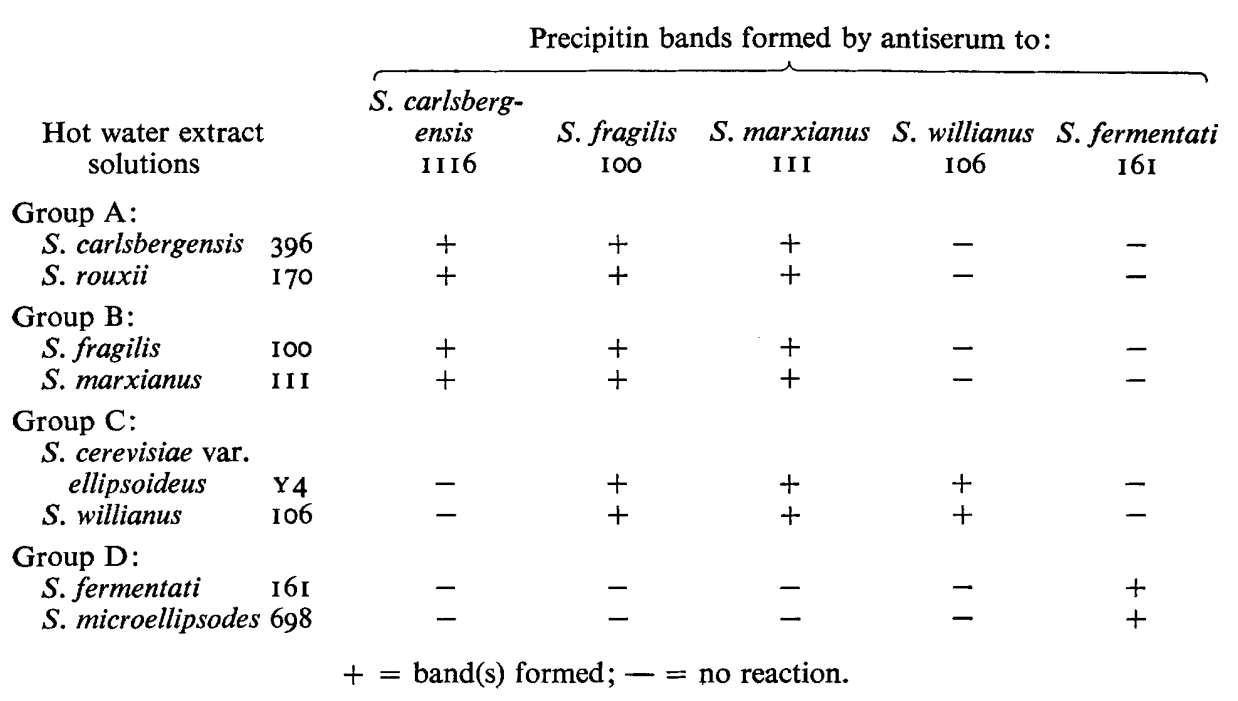

Gel-diffusion and slide agglutination tests with absorbed antisera. Specific antisera were prepared by absorption with the species recommended previously (Campbell, I968). In addition, Saccharomyces marxianus antiserum I I I was absorbed by $S$. rouxii I 70 to produce an alternative group B antiserum, but despite extensive absorption retained a significant activity in agglutination tests against the group C strains $S$. ellipsoideus Y 4 and $S$. willianus 106. A further absorption of $S$. marxianus I I antiserum by $S$. willianus 106 produced a group B-specific antiserum suitable for agglutination tests but too weak for gel-diffusion, even after concentration. The four standard group A, B, C and D antisera showed the expected specific agglutination of their appropriate groups (Table 6).

In gel-diffusion tests the group A and D antisera and Saccharomyces fragilis antiserum absorbed by $S$. rouxii produced single or double bands of identity strictly in accordance with group specificity with all four types of extract, but the group B antiserum prepared with $S$. marxianus antiserum absorbed by $S$. rouxii 170 consistently reacted with both group $B$ and group $C$ extracts, and the group antiserum reacted with both group B and group C extracts (Table 7). The amount of extract required for best 


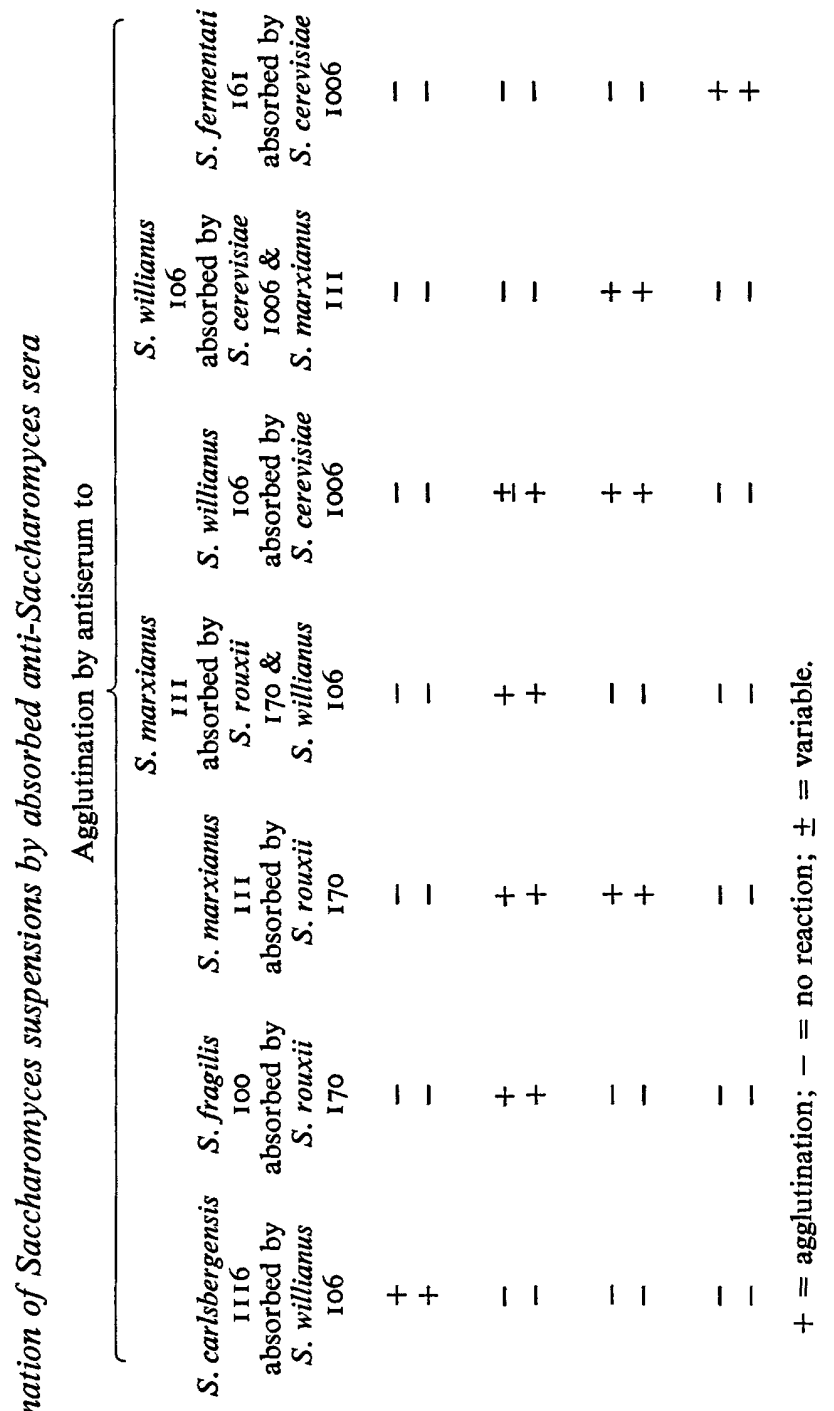

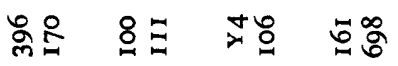

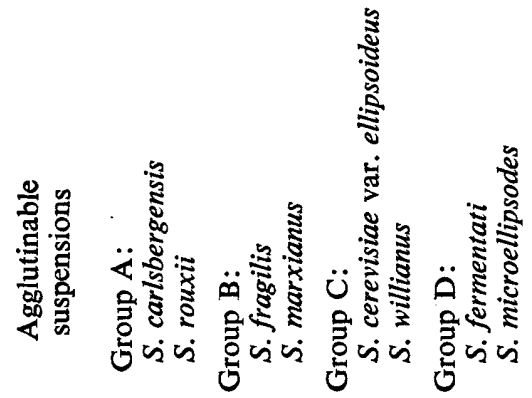


precipitin reaction with an antiserum varied with the type of extract. Generally, with antiserum of agglutination titre $I$ in 100 , the required concentrations of the homologous mannans, minimal medium or hot water extracts, and phenol extracts were $0.1 \mathrm{mg} . / \mathrm{ml} ., 2 \mathrm{mg} . / \mathrm{ml}$. and $5 \mathrm{mg} . / \mathrm{ml}$. respectively. At these concentrations heterologous extracts failed to form precipitin lines and the antisera were therefore groupspecific.

Table 7. Precipitin tests of Saccharomyces mannans, phenol extracts, minimal media and hot water extracts by absorbed anti-Saccharomyces sera

\begin{tabular}{|c|c|c|c|c|c|c|}
\hline \multirow{2}{*}{$\begin{array}{c}\text { Extract } \\
\text { solutions }\end{array}$} & & \multicolumn{5}{|c|}{ Precipitin bands formed by antiserum to: } \\
\hline & & $\begin{array}{l}\text { S. carlsberg- } \\
\text { ensis } \\
\text { I116 } \\
\text { absorbed by } \\
\text { S. willianus } \\
106\end{array}$ & $\begin{array}{c}\text { S. fragilis } \\
\text { 100 } \\
\text { absorbed by } \\
\text { S. rouxii } \\
\text { 170 }\end{array}$ & $\begin{array}{l}\text { S. marxianus } \\
\quad \text { II } \\
\text { absorbed by } \\
\text { S. rouxii } \\
\text { I70 }\end{array}$ & $\begin{array}{l}\text { S. willianus } \\
\text { 106 } \\
\text { absorbed by } \\
\text { S. cerevisiae } \\
\text { 1006 }\end{array}$ & $\begin{array}{l}\text { S. fermentati } \\
\text { I61 } \\
\text { absorbed by } \\
\text { S. cerevisiae } \\
\text { roo6 }\end{array}$ \\
\hline $\begin{array}{l}\text { Group A: } \\
\text { S. carlsbergensis } \\
\text { S. rouxii }\end{array}$ & $\begin{array}{l}396 \\
170\end{array}$ & + & - & $\overline{-}$ & $\overline{-}$ & $\overline{-}$ \\
\hline $\begin{array}{l}\text { Group B: } \\
\text { S. fragilis } \\
\text { S. marxianus }\end{array}$ & $\begin{array}{l}100 \\
\text { I I I }\end{array}$ & - & + & + & $\begin{array}{l}+ \\
+\end{array}$ & $\overline{-}$ \\
\hline $\begin{array}{l}\text { Group C: } \\
\quad \text { S. cerevisiae var. } \\
\text { ellipsoideus } \\
\text { S. willianus }\end{array}$ & $\begin{array}{r}\text { Y4 } \\
106\end{array}$ & - & - & $\begin{array}{l}+ \\
+\end{array}$ & + & $\overline{-}$ \\
\hline $\begin{array}{l}\text { Group D: } \\
\quad \text { S. fermentati } \\
\text { S. microellipsodes }\end{array}$ & $\begin{array}{l}\text { I6I } \\
698\end{array}$ & $\overline{-}$ & $\overline{-}$ & $\overline{-}$ & $\overline{-}$ & + \\
\hline & & $+=$ band(s) $f$ & ormed; $-=$ & no reaction. & & \\
\hline
\end{tabular}

Mannans extracted from yeasts are serologically active and give broad bands on immunodiffusion (Summers et al. 1964; Sandula et al. 1964). Suzuki et al. (1967) used yeast mannans prepared by autoclaving yeasts in citrate buffer to absorb yeast antisera. These preparations contained less than $0.5 \%$ nitrogen, insufficient to account for the observed inhibition of antibody activity. Suzuki et al. (I968) showed that oligosaccharides prepared from mannan of Saccharomyces cerevisiae caused $100 \%$ inhibition of the homologous antiserum. Thus, mannan alone can account for the observed antigenic activity.

Not all mannan of the cell wall is structural. Invertase (Neumann \& Lampen, 1967) and acid phosphatase (Boer \& Steyn-Parvé, 1966), both mannan-proteins, occurred in yeast cell walls. Neumann \& Lampen (1967) found that antiserum against Saccharomyces cerevisiae invertase formed a precipitin band with invertases from $S$. cerevisiae and a Saccharomyces hybrid strain, but no precipitin reaction was observed with cell wall mannan from $S$. cerevisiae. This agrees with the failure of commercial invertase, shown to contain mannan, to precipitate with our antisera to $S$. fragilis and $S$. willianus. Invertase may not be present in sufficient amount on the yeast cell surface to cause significant production of antibody.

The present paper shows that mannans, and preparations containing mannan, of 
yeasts of different serological groups, contain the antigenic group determinants. Extracts prepared by autoclaving in citrate buffer, shaking in hot water, shaking with phenol and directly from minimal medium gave similar results in immunodiffusion tests. Although phenol, hot water and minimal media extracts contained glucose, which may indicate the presence of a soluble glucan in the outer layers of the yeast cell wall, antigenic activity was approximately proportional to mannan content. Phenol extracts were used in the strongest concentrations and gave the least number of positive reactions (Table 3). Apart from their lower content of mannan, phenol extracts may be less specific due to their severe method of preparation. Traces of ribose detected by chromatography are thought to be due to ribonucleic acid since phenol and hot water extracts gave absorption spectra with peaks at $260 \mathrm{~m} \mu$ (unpublished results) as do purine/ pyrimidine bases. These absorption peaks could be removed by treatment of the extracts with trichloracetic acid; the modified extracts gave the same immunodiffusion results as untreated material.

Agglutination tests were much more sensitive than gel-diffusion tests and it was not surprising that some gel-diffusion tests failed to show precipitin bands corresponding to positive agglutination results. This was shown by unabsorbed antiserum to Saccharomyces carlsbergensis I I 6 in gel-diffusion tests with all extracts of the group $\mathrm{C}$ yeasts and the phenol extracts of the group B yeasts. Similarly, unabsorbed antiserum to either of the group B yeasts failed to give precipitin reactions with group A phenol extracts and unabsorbed antiserum to $S$. willianus 106 failed to show a precipitin reaction with group B hot-water extracts.

It was more surprising to find positive gel-diffusion results for corresponding negative agglutination tests as with unabsorbed Saccharomyces fragilis 100 antiserum and all group C extracts. These results suggested that both group B and C yeasts share an antigen but that $S$. fragilis has less of this antigen in its outer layer than $S$. marxianus. This suggestion is supported by the absorbed $S$. marxianus II I and $S$. willianus Io6 antisera giving positive agglutination and gel-diffusion results with both group $B$ and $\mathrm{C}$ yeasts and extracts (Tables 6 and 7). The failure of absorbed $S$. fragilis 100 antiserum to react with group $\mathrm{C}$ extracts (Table 7) may be due to the small amount of C-specific antibody present originally being further depleted by the absorptions; other absorbed antisera had to be concentrated to obtain a visible precipitin reaction. It was possible to make absorbed $S$. marxianus I I antiserum group-specific for agglutination tests by absorbing with a group C yeast plus $S$. rouxii (Table 6), but it is more convenient to use $S$. fragilis 100 antiserum absorbed by $S$. rouxii 170 as described previously (Campbell, I968). Similarly, the absorbed $S$. willianus Io6 antiserum could be made group-specific for agglutination tests by absorbing with a mixed suspension of $S$. marxianus and S. cerevisiae I006 (Table 6).

Campbell's group C antiserum was specific without this further absorption, partly due to the fact that for agglutination tests a standard titre was specified. Undiluted absorbed group $\mathrm{C}$ antiserum agglutinated Saccharomyces marxianus strongly and $S$. fragilis weakly, but at the specified dilution, viz. homologous agglutination at $\mathrm{I}$ in 5 but not at $I$ in 10, did not agglutinate either of these suspensions.

The activity shown by the minimal medium preparation suggests that mannan is dissolved from the cell surface as it is produced. This could have some role in yeast flocculence as the period of deflocculence coincides with the synthesis of mannan (Masschelein, Jeunehomme-Ramos, Castiau \& Devreux, 1963) and inhibition of man- 
nan synthesis by sodium fluoride (Chung \& Nickerson, I954) results in very flocculent yeasts. If, as Masschelein \& Devreux (1957) suggest, an external mannan 'masks' the active groups it is possible that, in fermentation, the balance between production and removal of the 'masking' mannan could be critical.

The authors wish to thank the Science Research Council for a grant held by R.H.G. during this work.

\section{REFERENCES}

BOER, P. \& STEYN-PARVÉ, E. P. (1966). Isolation and purification of an acid phosphatase from baker's yeast. Biochim. biophys. Acta 128, 400.

CAMPBell, I. (1968). Serological identification scheme for the genus Saccharomyces. J. appl. Bact. 3r, 515.

Camprell, I., Robson, F. O. \& Hough, J. S. (I968). Serological investigation of fining and flocculent yeasts. J. Inst. Brew. 74, 360 .

Chung, C. W. \& Nickerson, W. J. (1954). Polysaccharide synthesis in growing yeasts. J. biol. Chem. 208, 395.

Lodder, J. \& Kreger-VAn RIJ, N. J. W. (1952). The Yeasts, a Taxonomic Study. Amsterdam: NorthHolland Publ. Co.

Masschelein, C. A. \& Devreux, A. (I957). Flocculence et structure de la paroi cellulaire de la levure. Proc. European Brewery Convention Congr. Copenhagen, p. 194.

Masschelein, C. A., Jeunehomme-Ramos, C., Castiau, C. \& Devreux, A. (I963). Mechanism of phenotypic variations in the flocculence character of yeast. J. Inst. Brew. 69, 332.

Neumann, N. P. \& Lampen, J. O. (1967). Purification and properties of yeast invertase. Biochemistry, N.Y. 6, 468.

Opienska-Blauth, J., Charezinski, M. \& BerbeC, H. (1963). Tryptophane estimation of protein. Analyt. Biochem. 6, 69.

PARTRIDGE, S. M. (I949). Aniline hydrogen phthalate as a spraying reagent for chromatography of sugars. Nature, Lond. 164, 443.

Peat, S., Whelan, W. J. \& Edwards, T. E. (196I). Polysaccharides of baker's yeast. Part IV: Mannan. J. chem. Soc. 29.

Sandula, J., Kockova-Kratochvilova, A. \& Zamecnikova, M. (I964). Serologische Studie über Kulturhefen. Brauwissenschaft $\mathbf{1 7}$, I30.

SNIDER, I. J. \& Miller, J. J. (I966). A serological comparison of vegetative cells and acsus walls and the spore coat of Saccharomyces cerevisiae. Can. J. Microbiol. 12, 485.

StewART, T. S. \& BAllou, C. E. (I968). A comparison of yeast mannans and phosphomannans by acetolysis. Biochemistry, N.Y. 7, 1855 .

Summers, D. F., Grollman, A. P. \& Hasenclever, H. F. (I964). Polysaccharide antigens of Candida cell wall. J. Immunol. 92 , $49 \mathrm{I}$.

Suzuki, S. \& Sunayama, H. (I968). Studies on the antigenic activities of yeasts. II. Isolation and inhibition assay of the oligosaccharides from acetolysate of mannan of Candida albicans. Jap. J. Microbiol. 12, 413 .

Suzuki, S., Sunayama, H. \& Sarto, T. (I968). Studies on the antigenic activities of yeasts. I. Analysis of the determinant groups of the mannan of Saccharomyces cerevisiae. Jap. J. Microbiol. 12, 19.

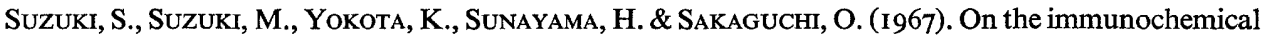
and biochemical studies of fungi. XI. Cross reactions of the polysaccharides of Aspergillus fumigatus, Candida albicans, Saccharomyces cerevisiae and Trichophyton rubrum against Candida albicans and Saccharomyces cerevisiae antisera. Jap. J. Microbiol. 11, 269.

TREVELYAN, W. E. (I966). Determination of some lipid constituents of baker's yeast. J. Inst. Brew. 72, I 84 .

TreVelyan, W. E., Procter, D. P. \& Harrison, J. S. (1950). Detection of sugars on paper chromatograms. Nature, Lond. r66, 444.

TsuchiYa, T., FUKaZAWA, Y. \& KaWAKITA, S. (1961). Serological classification of the genus Torulopsis. Sabouraudia I, I45.

WestPhal, O., LüDeritz, O. \& Bister, F. (1952). Über die Extraktion von Bakterien mit Phenol/ Wasser. Z. Naturforsch. $7 \mathbf{7}$, I48. 